Желобиов $\Phi . \Phi$. Багдадский пакт в отражении турецкого еженедельника «Акис» (50-е годы XX века) / Ф. Ф. Желобцов // Научный диалог. - 2022. - Т. 11. - № 1. - С. 379 394. - DOI: 10.24224/2227-1295-2022-11-1-379-394.

Zhelobtsov, F. F. (2022). Baghdad Pact as Reflected in Turkish Weekly "Akis" (50s of XX Century). Nauchnyi dialog, 11(1): 379-394. DOI: 10.24224/2227-1295-2022-11-1-379-394. (In Russ.).

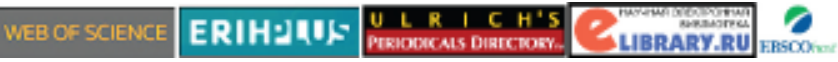

Журнал включен в Перечень ВАК

\section{Багдадский пакт}

\section{в отражении турецкого} еженедельника «Акис» (50-е годы XX века)

Желобцов Федот Федотович orcid.org/0000-0001-6106-740X доцент

кафедра восточных языков и страноведения,

Институт зарубежной филологии и регионоведения fedotzhel@mail.ru

Северо-Восточный федеральный университет имени М. К. Аммосова (Якутск, Россия)
Baghdad Pact as Reflected in Turkish Weekly "Akis" $\left(50^{\text {s }}\right.$ of XX Century)

Fedot F. Zhelobtsov

orcid.org/0000-0001-6106-740X

Associate Professor

Department of Oriental

Languages and Country Studies, Institute of Foreign Philology and Regional Studies fedotzhel@mail.ru

M. K. Ammosov North-Eastern Federal University (Yakutsk, Russia)

(C) Желобцов Ф. Ф., 2022 


\section{ОРИГИНАЛЬНЫЕ СТАТЬИ}

\section{Аннотация:}

Рассматривается история Багдадского пакта - своеобразного символа «холодной войны» в середине прошлого столетия на Ближнем Востоке, активным проводником которой стала Турция. Автор отслеживает развитие событий, вызвавших большой резонанс в обществе. Показано, что растущее протестное настроение нашло отклик на страницах еженедельника «Акис», первого нейтрального печатного органа Турции демократического направления, официально не принадлежавшего ни одной политической партии. Актуальность статьи видится в том, что известные в настоящее время перемены в ближневосточной политике Турции, нацеленные в первую очередь на учет национальных интересов страны, берут свое начало из региональных событий на Ближнем Востоке в 50-е годы прошлого столетия. Утверждается, что материалы «Акиса» в конкретном контексте, как своеобразные уроки прошлого, дают возможность понять и оценить многие нюансы современных непростых арабо-турецких отношений, корни которых уходят к событиям, имевшим прямое отношение к Багдадскому пакту.

\section{Ключевые слова:}

Багдадский пакт; вовлечение в блоки; политика США; арабо-турецкие отношения; оппозиция; критика ближневосточной политики.

\section{ORIGINAL ARTICLES}

\section{Abstract:}

The article deals with the history of the Baghdad Pact - a kind of symbol of the "cold war" in the middle of the last century in the Middle East, which Turkey became an active promoter of. The author traces the development of events that caused a great resonance in society. It is shown that the growing protest mood found its response on the pages of the "Akis" weekly, the first neutral democratic print organ in Turkey, which officially did not belong to any political party. The relevance of the article is seen in the fact that the well-known modern changes in the Middle East policy of Turkey, aimed primarily at taking into account the national interests of the country, originate from regional events in the Middle East in the 50s of the last century. It is argued that the materials of "Akis" in a specific context, as a kind of lessons from the past, make it possible to understand and appreciate many of the nuances of modern difficult Arab-Turkish relations, the roots of which go back to events that were directly related to the Baghdad Pact.

\section{Key words:}

Baghdad pact; involvement in blocks; US policy; Arab-Turkish relations; opposition; critique of Middle East politics. 


\section{Багдадский пакт в отражении турецкого еженедельника «Акис» (50-е годы XX века)}

(C) Желобцов Ф. Ф., 2022

\section{1. Введение $=$ Introduction}

Цель данной статьи - расширение знаний о специфических особенностях внешней политики Турции на Ближнем Востоке в самый тяжелый период ее истории во время правления Демократической партии (19501960 годы), а именно: попытка проследить события, характеризующие участие страны в Багдадском пакте, на фоне взаимоотношений с арабскими странами.

Хронологические рамки статьи охватывают 50-е годы XX века.

Практическая значимость статьи состоит в том, что ее результаты могут внести вклад в дискуссию о переменах в ближневосточной политике Турции в настоящее время.

Актуальность и научная значимость избранной темы приобретают сегодня новое звучание в свете геополитических изменений, происходящих на Ближнем Востоке. Бесконечные кризисные ситуации в этом регионе, их непредсказуемость и отсутствие ясных перспектив разрешения невольно вынуждают вновь обратиться к перипетиям исторических событий недавнего прошлого в этом регионе, уроки которых могут способствовать лучшему пониманию эволюции всей ближневосточной политики Турции.

Объектом исследования стала именно Турция, наиболее крупное и стратегически важное государство на Ближнем Востоке, которое в 50-е годы XX века явилось центром международной напряженности и региональным «зачинщиком» «холодной войны» в регионе. Углубление знаний об основных тенденциях и особенностях ближневосточной политики Турции вполне может позволить более объективно оценить современное ее состояние и спрогнозировать возможные перемены в ней.

Переговоры о создании на Ближнем Востоке военно-политического блока при большой заинтересованности США и Англии велись уже сразу после окончания Второй мировой войны. Региональным инициатором создания подобного блока стала Турция. Сам Багдадский пакт был подписан 24 февраля 1955 года во время визита в Ирак турецкой правительственной делегации во главе с премьер-министром А. Мендересом. Официальное оформление состоялось в Багдаде 19-22 ноября 1955 года на учредительном совещании с участием премьер-министров Турции, Ирака, Ирана, Ан- 
глии и Пакистана. Пакт просуществовал на Ближнем Востоке всего около трех лет. Но его история и судьба до сих пор вызывают самые различные оценки турецких исследователей. Так, в современной турецкой энциклопедии вступление Турции в Багдадский пакт оценивается в целом как «поспешное» [Türkiye Ansiklopedisi, 1983, s. 2073].

На взгляд автора, изучение данной темы на основе турецких источников было бы более полным с учетом привлечения материалов единственного в те годы демократически настроенного журнала «Акис», который был задуман его основателями как аналог американского журнала «Тайм». Материалы популярного еженедельника рельефно отражали рост оппозиционных настроений в стране, подлинное отношение турецкого общества к антинародной политике правительства, к Демократической партии (далее - ДП), находившейся у власти в 50-е годы прошлого столетия, и особенно к участию Турции в деятельности агрессивного Багдадского пакта.

\section{2. Материал, методы, обзор = Material, methods, review}

Автором предпринята попытка критического анализа и синтеза тематических материалов, которые стали методологической основой в подготовке статьи.

В статье проведен сравнительный анализ доступных российских, турецких и западноевропейских публикаций о политической ситуации, связанной с Багдадским пактом. Основной материал собран и переведен автором на русский язык в 1994 году, в период его работы в архиве Турецкого исторического общества в г. Анкаре Турецкой Республики. В то время данный материал был недоступен для российского читателя. Автору удалось поработать и с номерами еженедельника «Акис», конфискованными властями в 50-е годы. Новизна настоящего исследования состоит в том, что в научный оборот вводятся источники, большинство из которых не переведены на русский язык, в том числе публикации турецких авторов, недоступные для общего пользования. Цитаты, приводимые в тексте, переведены нами.

Все исследованные материалы были подвергнуты тщательной проверке и сопоставлению с другими иностранными источниками, в том числе российскими. Большую помощь в этой работе оказали воспоминания и мемуары современников событий изучаемого периода (лидера турецкой оппозиции Исмета Иненю, сторонника ДП Назыма Берксана, официальных биографов Народно-республиканской партии (НРП) и ДП Айдемира Шефкета Сюррейя, Джема Эрогула, владельца и главного редактора еженедельника «Акис» Метина Токера). Значительную помощь оказала работа болгарского ученого Дженгиза Хакова по истории Турции новейшего периода. 
Кроме того, научная новизна статьи заключается и в изучении малоисследованной части турецкой публицистики. По данным автора, до настоящего времени в Турции нет исследований на основе информации из еженедельника «Акис». Значимость «Акиса» состоит в том, что он был первым независимым демократическим органом турецкой печати в 50-е годы прошлого столетия. Публикации на его страницах углубляют и уточняют многие данные об эволюции внешней политики Турции на Ближнем Востоке.

\section{3. Результаты и обсуждение $=$ Results and Discussion}

\section{1. «Акис» - Багдадский пакт}

В современной турецкой научной литературе разброс мнений и оценок участия Турции в пакте остаётся очень широким: от стремления оправдать до открытого восхваления. Так, историк К. Гюрюн, оправдывая политику своей страны, считает, что «такие небольшие государства, как Турция, для обеспечения безопасности своих границ вынуждены были не упускать ни одной возможности» [Gürün, 1983, s. 354]. В противовес ему Дж. Эрогул - официальный биограф бывшей Демократической партии Турции открыто пишет: «В итоге, благодаря усилиям нашего правительства, на Ближнем Востоке был создан новый Атлантический пакт, защищавший интересы Запада» [Eroğul,1970, s. 114].

Однако при всех различиях большинство турецких авторов едины во мнении, что заключение пакта явилось сильным фактором ухудшения арабо-турецких отношений в 50-е годы. Ведущий специалист по изучению арабо-турецких отношений О. Кюркчюоглу оценивает документ о создании военно-политического блока на Ближнем Востоке как вообще конец существованию мирного периода в арабо-турецких отношениях. «Турецко-арабские отношения, - пишет он, - полностью разорваны. Таким образом, Багдадский пакт стал поворотным пунктом» [Kürkçüoğlu, 1972, s. 79]. Не вызывает сомнения, что подписание данного документа являлось одним из ключевых вопросов в политической повестке Турции. «До заключения Багдадского пакта, - поясняет политолог Х. Умман, - Турция регулировала свои отношения со странами Ближнего Востока посредством двусторонних контактов. Однако с созданием этого военно-политического союза взаимоотношения стали устанавливаться в его рамках, что сделало пакт краеугольным камнем всей ближневосточной политики Турции» [Ümman,1958, s. 107].

В то же время турецкие авторы многие годы использовали избитые мифы о «советской угрозе», повторяя, что именно она вынудила Турцию вступить в Багдадский пакт [Aydemir, 1968, s. 390]. Не преминули они «включить» и арабские страны в число «виновников» краха Багдадского 
пакта. «В любом случае, — пишет И. Сойсал, — из-за того, что ближневосточные дела между арабами были в высшей степени запутаны как в региональном, так и в мировом масштабах, Багдадский пакт не смог стать таким сильным и жизнеспособным, как HATO» [Soysal, 1955; Bağdat Pakt1, 1991a, s. 227].

Часть турецких авторов едины во мнении, что отказ США официально войти в Багдадский пакт - это лишь манёвр, который не изменил их главенствующей роли в данном союзе. «США не стали официальным членом пакта, - подчеркивает О. Кюркчюоглу, — и это никак не повлияло на его реальный статус» [Kürkçüoğlu, 1972, s. 69]. Более того, другие считают, что Багдадский пакт практически превратился в американскую организацию на Ближнем Востоке [Aydemir,1968, s. 333]. Таким образом, стало совершенно ясно: вместе с отказом официально вступить в Багдадский пакт США дали свое согласие на активное участие в деятельности его комитетов [Olaylarla ...,1969, s. 288].

Министр иностранных дел Турции Ф. Кёпрюлю, выступая 26 февраля 1955 года в Великом Национальном собрании (парламенте) по поводу создания Багдадского пакта, официально охарактеризовал позицию турецкого правительства: «Сегодня в мире существует агрессивный фронт, а с другой стороны - оборонный фронт. Нейтралитету нет места» [Soysal, 1955; Bağdat Paktı, 1991b, s. 201].

Еженедельник «Акис», как и вся турецкая оппозиция, активно поддерживал усилия правительства ДП по вовлечению арабских стран в создаваемый военно-политический блок. И он же был полностью солидарен с официальной политикой Анкары на Ближнем Востоке, рассматривавшей все происходившие события в регионе как столкновение интересов Запада и Востока.

В начале 1955 года турецкая делегация во главе с премьер-министром А. Мендересом осуществила официальный визит в ряд стран Ближнего Востока с целью вовлечь их в планировавшийся военно-политический блок. «Акис» внимательно следил за ходом этой поездки. Надо заметить, что еженедельник с самого начала высказывал сомнения в быстром достижении ее целей. «Нельзя сказать, — осторожно замечает журнал, что поездка Мендереса вызовет в арабских странах воодушевление» [Bir politikanın ..., 1955, № 34, s. 9].

Журнал не скрывал и своих опасений: «Невозможно скрыть существующую разницу между нашими взглядами. Например, Ирак и вместе с ним многие страны Ближнего Востока хотят видеть Арабский Союз основой будущей системы обороны региона. Что это значит? Только одно - Турция должна войти в Арабский Союз. В таком случае Арабский Союз теряет своё главное качество. Они желают, чтобы была найдена приемле- 
мая формула, в которой все арабские страны вошли бы в новую систему. Но для этого сейчас время ещё не пришло» [Orta Doğu, 1955, № 35, s. 9]. После завершившихся успешных переговоров с иракским руководством «Акис» с удовлетворением пишет: «Сейчас перед Турцией стоит задача объединить другие арабские страны путём подписания договора с каждым по отдельности либо присоединением их к турецко-иракскому пакту» [D1ş politikamız, 1955, № 68, s. 11]. В то же время нельзя не заметить холодности и недружелюбия публикаций в журнале относительно работы правительства премьер-министра Нури Саида в Ираке: «Нури Саид держится у власти лишь благодаря закрытию парламента и университетов» [Orta Doğu, 1957, № 140, s. 8].

После Ирака турецкая делегация прибыла в Ливан, однако переговоры потерпели неудачу. «Акис», так же, как и правительство Турции, возлагавший определённые надежды на ливанское руководство, принявшее «доктрину Эйзенхауэра», с сожалением замечает: «В случае, если Мендерес смог бы убедить ливанских лидеров присоединиться к турецко-иракскому пакту, был бы сделан очень важный шаг на пути создания на Ближнем Востоке настоящей оборонной системы. Переговоры прошли в очень дружеской обстановке, однако ливанцы не смогли проявить мужество, проявленное премьер-министром Ирака. Переговоры отложены. Другими словами, Ливан ещё не принял определённого решения. Все усилия и убеждения турецкой делегации результатов не дали: Ливан всё ещё воздерживается» [Başarılı işler, 1955a, № 37, s. 7]. Журнал, сообщая о семи депутатах ливанского парламента, которые подали в отставку в знак недовольства прозападной политикой своего правительства, с опасением предупреждает: «Если так обстоят дела в Ливане, то очень легко представить настроения в других арабских странах» [Müstafi milletvekilleri, 1957, № 154, s. 13].

Присоединение же Пакистана к турецко-иракскому соглашению «Акис» расценил как его стремление стать ближе к Западу: «Привязка Пакистана означает подписание договора с Турцией, которая является важным восточным форпостом Запада» [Orta Doğu, 1955, № 35, s. 9].

В связи с провалом попытки вовлечения Ливии в пакт главный редактор «Акиса» М. Токер, касаясь результатов поездки А. Мендереса в Триполи в январе 1957 года, признает: «Чего мы добились в ходе переговоров с ливийскими братьями, кроме как ничего не стоящего коммюнике?» [Toker, Mutab1k ..., 1957, № 144, s. 9]. Журнал, оценивая визит президента Дж. Баяра в Ливию, лишь констатирует: «Ливия не испытывает симпатий к Багдадскому пакту, поскольку она свою политику ведёт в рамках Арабского Союза. С этой точки зрения неправильно думать, что поездка выйдет за рамки обычного протокольного визита» [Orta Doğu, 1958, № 196, s. 16]. 
Турецкое руководство рассчитывало на то, что через членство в созданной в 1958 году Ирако-Иорданской Федерации Иордания попадёт под влияние Багдадского пакта без официального присутствия в нём. «Акис» сразу расценил создание Ирако-Иорданской Федерации как недальновидность политики Турции на Ближнем Востоке. М. Токер в большой статье «Багдадский пакт без Багдада», критикуя создание и признание Турцией этой Федерации, пишет: «Нам необходимо реалистично взглянуть на последние события на Ближнем Востоке и признать, что наши действия являются результатом чрезмерно поспешных действий» [Toker, Bağdatsız ...,1958a, № 198, s. 9]. «Багдадский пакт, - предупреждает журнал, - из-за них обречён на потерю Багдада» [Orta Doğu, 1958, № 198, s. 6]. Перепечатки публикаций из западной прессы на страницах «Акиса» также свидетельствуют о том, что «с образованием Федерации подписан смертный приговор Багдадскому пакту» [Orta Doğu, 1958, № 199, s. 22].

В случае с неудачей вовлечения Иордании в пакт «Акис» открыто обвинил Англию: «Англия, принуждая иорданских руководителей, поспешила и срубила сук, на котором сидела. Четыре министра иорданского правительства подали в отставку, обвинив Англию во вмешательстве во внутренние дела Иордании. Последние события явно демонстрируют нежелание страны присоединиться к Багдадскому пакту. Английский же нажим уничтожил последние надежды в этом деле» [Ürdün, 1956, № 89, ss. 17-18]. Одновременно журнал признавал: «Самый важный фактор, который постоянно влечёт Иорданию в Нейтральный арабский союз, - это, несомненно, создание Багдадского пакта» [Çevrilen dirsek, 1956, № 106, s. 19]. «Если сейчас Иордания выберет сторону этого союза, - серьезно предостерегает “Акис", — то Багдадский пакт потеряет всю свою значимость» [Iki blok, 1956, № 89, s. 17].

В отношении арабских стран, занявших резко отрицательную позицию в оценке Багдадского пакта, «Акис» требовал проведения более жёсткой политики. Дж. Бабан, председатель комиссии Великого национального собрания (BНC) Турции по внешним делам, предупреждал о том, что политика Египта была предсказуема [Orta Doğu, 1954, № 8, s. 11]. Одновременно журнал признавал, что только с участием Египта может быть создана настоящая система безопасности в регионе: «Другие арабские страны без него не будут участвовать в этом деле» [Ibid., s. 11]. «Правительство Каира, — пишет “Акис”, — не хочет садиться за стол переговоров для принятия решений. В таком случае необходимо его принудить к этому» [Başarılı işler, 1955b, № 37, s. 7].

Лидер турецкой оппозиции И. Иненю не скрывал того, что ему не нравится чересчур мягкая политика в отношении Египта. Он расценил усилия Турции по созданию системы обороны на Ближнем Востоке как за- 
искивание перед Каиром, о чем сообщает еженедельник [Muhalefetle ..., 1955, № 40, s. 4]. Такое же отношение было и у «Акиса» к Сирии. О переговорах с ее руководством «Акис» с самого начала пишет, что турецкий премьер-министр и сам не верил в возможность присоединения Сирии к турецко-иракскому соглашению: «Переговоры, проведённые в Дамаске, не дали других результатов, кроме ожидаемых. В Сирии ситуация ещё не созрела» [Başarılı işler, 1955 с, № 37, s. 8]. «К сожалению, - констатирует журнал, — никак не удалось убедить правительство Дамаска вступить в Багдадский пакт» [Türkiye ve ..., 1956, № 134, s. 17].

В период сирийского кризиса осенью 1957 года «Акис» не возражал и против возможности совместных действий государств-членов Багдадского пакта против Сирии. В то же время не преминул заметить, что «эти действия были бы ещё эффективней, если бы США решили присоединиться к нему» [Цит. по: Ama bu sefer de ..., 1955, № 40, s. 17]. Страницы журнала были полны негативной информации о тяжёлом внутреннем и экономическом положении Сирии [Ваşı dertte..., 1956, № 139, s. 7]. Примечательно, что после бесславного окончания сирийского кризиса политический обозреватель «Акиса» Х. Авджыоглу пророчески заметил: «Для турецкого правительства, которое верит, что путь к спасению Ближнего Востока лежит через Багдадский пакт, есть уроки сирийских событий» [Avc1oğlu, Orta Doğudaki Yeni ..., 1957, № 176, s. 17].

«Акис» занимал принципиально враждебную позицию в отношении Саудовской Аравии из-за её пропаганды против Багдадского пакта в арабском мире: «Самое важное - Саудовская Аравия не изменила своей позиции против Багдадского пакта» [Avcıoğlu, D., 1957, № 147, s. 16].

В начале 1956 года «Акис», подводя итоги вовлечения арабских стран в пакт, хладнокровно констатирует: «Наши надежды до сих пор не оправдались, и даже нет ни малейшего намёка на то, что они осуществятся в этом году [Geçen y1la ..., 1956, № 87, ss. 12-13].

Единственный корреспондент журнала за рубежом А. Балкан подверг открытой критике генерального секретаря МИД Турции Мухаремма Нури Бирги за его слова на Совете НАТО в Париже, что он считает Багдадский пакт своим дитя. «“Дитя” генерального секретаря, - саркастически пишет А. Балкан - изначально родился нежизнеспособным рахитиком» [Balkan, Muharrem ..., 1957, № 139, s. 15].

На своих страницах «Акис» постоянно отмечает значимость союзнических отношений Турции с Западом. Отмечая 5-ю годовщину основания НАТО, журнал подчёркивал, что «интересы Турции гораздо больше связаны с НАТО и Европейским сообществом, чем с Багдадским пактом» [Цит. по: Orta Doğu, 1957, № 147, s. 10]. 


\section{2. «Акис» об отказе США вступить в пакт}

Главным инициатором создания военно-политического блока на Ближнем Востоке были США. Инициатива возникла с приходом к власти администрации Дуайта Эйзенхауэра, которая таким образом пыталась реализовать цель противостоять проникновению СССР на Ближний Восток [Kurban, 2014, s. 259]. По приглашению турецкого правительства в Анкару прибыл министр иностранных дел США Джон Фостер Даллес. На этих переговорах и были заложены основы будущего Багдадского пакта [Ağayev, 2010, s. 131].

Тема участия США в Багдадском пакте занимала в журнале исключительно много места. Оппозиция, как и правительство, единодушно желала и неустанно требовала, чтобы США стали официальным членом пакта: «Америка должна присоединиться к Багдадскому пакту. Этот вопрос очень важен и для НАТО. Считать ближневосточные вопросы не затрагивающими непосредственно этот альянс в высшей степени ошибочно. Между НАТО и Багдадским пактом необходимо создать особые отношения» [Toker, Kibris ..., 1957, № 189, s. 8]. Лидер НРП И. Иненю постоянно подчеркивал необходимость укрепления связей Багдадского пакта с НАТО [İnönü,1956, s. 349]. Д. Авджыоглу без иронии добавлял: «Нет необходимости и в “доктрине Эйзенхауэра”. Достаточно было Америке присоединиться к Багдадскому пакту. И сделать это надо было гораздо раньше» [Avcıoğlu, Orta Doğudaki ..., 1957, № 144, s. 17].

\section{3. «Акис» и критика ближневосточной политики Турции}

Примечательно, что в связи с явными провалами планов по вовлечению арабских стран в военно-политический блок «Акис» первым среди СМИ страны затронул в критическом духе всю ближневосточную политику Турции. При этом журнал «вину» за неудачи попытался в первую очередь переложить на Англию. «Багдадский пакт, — пишет А. Балкан, к которому мы присоединились по настоянию Англии, навлёк на нас со всех сторон молнии враждебности. Арабские страны повернулись к нам спиной. Каковы же интересы турецкой нации в этих событиях? Англия оставила нас лицом к лицу с враждебностью арабских стран» [Balkan, Dış Politikamız ..., 1956, № 100, s. 19].

Критические публикации о Багдадском пакте и всей политике Турции на Ближнем Востоке резко умножились в период суэцкого кризиса 1956 года. Участие в тройственной агрессии одного из членов пакта Англии - и негласная поддержка агрессоров со стороны другого его члена — Турции - окончательно дискредитировали этот военно-политический блок в арабском мире. 
«Акис» с самого начала кризиса отнёсся скептически к возможностям Багдадского пакта. «“Зафер” (правительственная газета. - Ф. Ж.), - пишет журнал, - в своих воплях о силе Багдадского пакта явно поторопился» [Süveyş. Fırtınadan ..., 1956, № 132, s. 14].

«Акис» обрушился с критикой на членов пакта в связи с их реакцией на тройственную агрессию. Он был недоволен итогами их чрезвычайного совещания в Тегеране 7 ноября 1956 года и принятым там документом. «Их заявление после начала военных действий, — пишет журнал, - далеко от понимания сути истинных причин суэцкого кризиса. В нем говорилось о том, что Египет подвергся “несправедливой агрессии”, открыто поддерживался Арабский Союз, предусматривались санкции против Израиля. Всё это вызывает удивление, так как пакт не направлен против законных интересов арабских стран» [Ergin, Haricî ..., 1956, № 135, s. 9].

«Акис» поддержал недовольство правительства в связи с отстранением Англии от совместных заседаний стран-участниц пакта в период суэцкого кризиса (Англия не присутствовала на сессиях до июня 1957 года) из-за её участия в агрессии против Египта. И. Иненю, лидер Народно-республиканской партии, выступая в меджлисе, заявил, что «он не согласен с существованием Багдадского пакта без Англии» и что «без Англии пакт не имеет никакой ценности» [Цит. по: Avcıŏglu, Bağdat pakt ..., 1957 , № 141 , s. 14].

\section{4. «Акис» и Багдадский пакт в период иракской революции 1958 года}

В 1958 году в Ираке произошёл революционный переворот, свергнувший прежний монархический режим. Новое иракское правительство сразу объявило о независимой внешней политике провозглашенной Иракской Республики и выходе из Багдадского пакта.

В связи со случившимся «Акис» вновь обрушился с критикой на всю ближневосточную политику Турции. «Почему так происходит? - сокрушается журнал. - А потому, что наша политика против арабов ошибочна с самого начала. Необходимо знать арабский мир, как условие, знать его чувства. Льстить арабским лидерам, давать в их честь банкеты, напоминающие сказки из 1001-й ночи, не является плодотворной тактикой» [Dış politika alfabesi, 1958, № 220, s. 11].

\section{5. «Акис» и выход Ирака из Багдадского пакта}

24 марта 1959 года состоялся официальный выход Ирака из Багдадского пакта. Необходимо отметить, что «Акис» ещё до выхода Ирака из пакта серьёзно предупреждал: «Пока Багдад остаётся центром пакта, его шансы 
стать для арабов притягательным центром как Каир не увеличатся. Блок находится сейчас в самом эпицентре бури. Из-за того, что между партнёрами фактически никогда не существовало единства интересов, Багдадский пакт никогда не мог крепко стоять на ногах. Однако сейчас необходимо признать: мы находимся непосредственно перед опасностью остаться без Багдада» [Toker, Bağdatsız Bağdat ..., 1958b, № 198, s. 9].

Прямо накануне выхода Ирака из пакта «Акис» с тревогой возвещал: «Надо спасать блок, поскольку падение Ирака, не приведи Всевышний, станет катастрофой для Запада» [Sallanan pact..., 1958, № 194, s. 15]. «“Измена" Ирака, - констатирует журнал, - стала сюрпризом как для Министерства иностранных дел Турции, так и для турецкого общественного мнения. Однако для тех, кто внимательно следит за событиями, нет ничего удивительного. Какие из арабов могут быть друзья, “Акис” писал давно» [Tarihi Arap ..., 1957, № 189, s. 6].

Турецкие руководители неудачно пытались предотвратить выход Ирака из пакта сразу после иракской революции 1958 года. Но, несмотря на все усилия, уже ничто не могло предотвратить развал военно-политического блока: в недолгой его истории начался период кризиса, из которого он так и не вышел до своего краха. 28 июня 1958 года в Лондоне состоялась конференция стран-членов Багдадского пакта без участия Ирака. «Можно считать, — резюмирует К. Гюрюн, — что пакт на этой дате закончил своё существование» [Gürün, 1983, s. 360].

\section{6. Конец Багдадского пакта. Создание СЕНТО}

Выход Ирака из блока предрешил судьбу Багдадского пакта. После его краха был образован блок СЕНТО (Merkezi Andlaşma Teşkilâtı): «Организация центрального договора (сокр. от англ. The Central Treaty Organization CENTO) - агрессивный военно-политический блок; до официального выхода из него Ирака (24 марта 1959) - Багдадский пакт. В состав СЕНТО входят Англия, Иран, Пакистан, Турция. США официально не являются членом СЕНТО, но входят в его комитеты и пользуются в этом блоке особыми правами» [СЕНТО, 1969, т. 12, стб. 769] Его штаб был учреждён в Анкаре. Влияние США стало определяющим, и Англия отошла на второй план.

Турецкий исследователь И. Сойсал отмечает, что в основу СЕНТО легло военное соглашение, заключённое между Турцией и Ираком еще 24 февраля 1955 года: «Не было внесено никаких изменений в текст Устава CЕНТО, скопированного из Багдадского пакта» [Soysal, Seventy years ..., 1991, p. 57].

Турецкая оппозиция осталась верна СЕНТО и после государственного переворота 1960 года. И. Иненю заявил, что НРП в период пребывания 
в оппозиции поддерживала политику верности НАТО и СЕНТО, поскольку это — «наша национальная политика» [Цит. по: Diş Politika. CHP ..., 1961, s. 35].

\section{4. Заключение $=$ Conclusions}

Материалы журнала «Акис» отражают реальное состояние дел и тенденций в сфере внешней политики Турции в 50-е годы на Арабском Востоке, многие из которых актуальны и поныне.

В основе изменений последних десятилетий во внешней политике Турции на Ближнем Востоке лежит, как можно наблюдать, стремление турецкого руководства к более объективному анализу событий в регионе, а также желание подходить к их рассмотрению с точки зрения национальных интересов страны. Суть политики «комплексной равноудалённости» как основы меняющейся ближневосточной политики - это соблюдение своих обязательств перед западными партнёрами и восстановление связей с арабскими соседями на базе культурной и цивилизационной близости.

Примечательно то, что после краха Багдадского пакта, а затем его преемника СЕНТО Турция отказалась вообе входить в какой-либо военный блок на Ближнем Востоке, который бы вызвал негативную реакцию арабов, и все свои усилия сосредоточила на выстраивании двусторонних отношений с соседями по региону. Турция, по всей видимости, приняла решение вести политику, близкую к арабам, но без принятия на себя какихлибо обязательств в регионе.

Малоизвестные материалы еженедельника «Акис» проливают дополнительный свет на эволюцию современной ближневосточной политики Турции. Они с определённой долей уверенности дают право предположить, что новые веяния в турецкой политике на Ближнем Востоке уходят своими корнями в переломные события 50-х годов прошлого столетия. «Акис» первым из турецких СМИ выступил с критикой и Багдадского пакта, и всей политики Турции в этом регионе. Безусловно, есть за что критиковать еженедельник «Акис», но важно понимать: он боролся за сохранение тех достигнутых демократических свобод в своей стране, которые были возможны в условиях тоталитарного и антинародного режима правящей Демократической партии.

\section{Источники и принятые сокращения}

1. СЕНТО // Советская историческая энциклопедия / ред. Е. М. Жуков. - Москва : Издательство «Советская энциклопедия», 1969. - Т. 12. — 976 стб.

2. Ama bu sefer de Suriye // Akis. - C. 3. - 1955. - 12 Şubat. — № 40. - S. 17.

3. Avcıoğlu D. Orta Doğudaki Boşluk / D. Avcıoğlu // Akis. - C. 9. - 1957. 2 Mart. — № 147. — S. 16. 
4. Avcıoğlu D. Bağdat pakt meselesine dair / D. Avcıŏglu // Akis. - C. 9. - 1957. 19 Осак. - № 141. - S. 14.

5. Avcıoğlu D. Orta Doğudaki Soğuk harp / D. Avcığlu // Akis. - C. 9. - 1957. 9 Şubat. — № 144. - S. 17.

6. Avcıŏlu H. Orta Doğudaki Yeni Hava / H. Avcığlu // Akis. - C. 11. - 1957. 21 Eylûl. - № 176. - S. 17.

7. Balkan A. Dış Politikamız Ne Zaman Bir Düzene Kavuşacaktır? / A. Balkan // Akis. C. 6. - 1956. - 7 Nisan. - № 100. - S. 19.

8. Balkan A. Muharrem Nuri Birgi ile niçin mutabık değiliz / A. Balkan // Akis. C. 9. - 1957. - 5-6 Ocak. — № 139. - S. 15.

9. Başarılı işler // Akis. - C. 3. - 1955. - 22 Ocak. - № 37. - S. 7, 8 .

10. Başı dertte Suriye // Akis. - C. 9. - 1956. — 5 Осак. — № 139. - S. 7.

11. Bir politikanın başarısı // Akis. - C. 2. - 1955. - 1 Ocak. - № 34. - S. 9.

12. Çevrilen dirsek // Akis. — C. 6. - 1956. - 19 Mayıs. — № 106. — S. 19.

13. Dış politika alfabesi // Akis. - C. 13. - 1958. - 26 Temmuz. — № 220. - S. 11.

14. Dış politikamız // Akis. - C. 4. - 1955. - 27 Ağustos. — № 68. - S. 11.

15. Ergin F. Haricî siyaset / F. Ergin // Akis. - C. 6. - 1956. - 8 Aralık. — № 135. — S. 9.

16. Geçen yıla bakarken // Akis. - C. 6. - 1956. - 7 Осак. — № 87. — Ss. $12-13$.

17. Iki blok // Akis. - C. 6. - 1956. - 21 Ocak. — № 89. - S. 17.

18. Muhalefetle iktidarın birleştirdiği nokta // Akis. - C. 3. - 1955. - 12 Şubat. № 40. - S. 4.

19. Müstafi milletvekilleri // Akis. - C. 10. — 1957. — 25 Mayıs. — № 154. — S. 13.

20. Orta Doğu // Akis. - C. 1. - 1954. - 3 Temmuz. - № 8. - S. 11.

21. Orta Doğu // Akis. - C. 1. - 1955. - 8 Ocak. - № 35. - S. 9.

22. Orta Doğu // Akis. - C. 9. - 1957. - 12 Ocak. - № 140. - S. 8.

23. Orta Doğu // Akis. - C. 9. - 1957. - 2 Mart. - № 147. - S. 10.

24. Orta Doğu // Akis. - C. 12. - 1958. - 8 Şubat. - № 196. - S. 16.

25. Orta Doğu // Akis. - C. 12. - 1958. - 22 Şubat. — № 198. - S. 6.

26. Orta Doğu // Akis. — C. 12. — 1958. - 1 Mart. - № 199. - S. 22.

27. Sallanan pact // Akis. - C. 12. - 1958. - 25 Ocak. — № 194. - S. 15.

28. Süveyş. Fırtınadan sonra // Akis. - C. 8. - 1956. - 17 Kasım. — № 132. - S. 14.

29. Tarihi Arap dostlarımız // Akis. - C. 11. - 1957. - 21 Aralık. — № 189. — S. 6.

30. Toker M. Mutabık olmadığımız politika / M. Toker // Akis. - C. 9. — 1957. — 9 Şubat. — № 144. - S. 9 .

31. Toker M. Kibrıs politicası / M. Toker // Akis. - C. 11. - 1957. - 21 Aralık. № 189 . - S. $8-9$.

32. Toker M. Bağdatsız Bağdat Paktı / M. Toker // Akis. - C. 12. - 1958. - 22 Şubat. — № 198. - S. 6, 9 .

33. Türkiye ve Orta Doğu // Akis. - C. 6. — 1956. - 1 Aralık. — № 134. — S. 17.

34. Ürdün // Akis. - C. 6. - 1956. - 21 Осак. — № 89. - S. 17-18.

\section{Литература}

1. A ğayev E. Atatürk'ün Vefatının Sovyet Basınında Yansıması / E. Ağayev // Cumhuriyet Tarihi Araştırmaları Dergisi. Hacettepe Üniversitesi Atatürk İlkeleri ve İnkılap Tarihi Enstitüsü. - C. 6. - 2010. - Y11. — Ss. 131-157.

2. Aydemir Ş. S. İkinci adam : İsmet İnönü. Üçüncü ve Son Cilt (1950-1964) / Ş. S. Aydemir. — İstanbul : Remzi Kitabevi, 1968. — 578 s. — ISBN 9789751400376. 
3. Dış Politika. CHP. Araştırma ve Yıyın Bürosu. Yayın № 25. — Ankara, 1961. — $74 \mathrm{~s}$.

4. Eroğul C. Demokrat Parti (Tarihi ve ideolojisi) / C. Eroğul. — Ankara : Ankara Üniversitesi, 1970. - $227 \mathrm{~s}$.

5. Gürün K. Dış ilişkiler ve Türk politikası (1939-den günümüze kadar) / K. Gürün // Ankara Üniversitesi Siyasal Bilgiler Fakültesi yayınları № 531. — Ankara : A.Ü.S.B.F., 1983. $457 \mathrm{~s}$.

6. İn̈nü İ. Muhalefetde. 1950-1956. Konuşmaları, demeçleri, mesajları, sohbetleri ve yazılarıyla / I. İnönü. — İstanbul : Siralar Matbaası, 1956. — 428 s.

7. Kurban V. 1950-1960 Yıllarında Türkiye ile Sovyetler birliği Arasındaki ilişkiler / V. Kurban // Çağdaş Türkiye Tarihi Araştırmaları Dergisi (Journal of modern Turkish history studies). - C. XIV/28. - 2014. — (Bahar/Spring). — Ss. 253-282.

8. Kürkçüoğlu Ö. Türkiyenin Arap Orta Doğusuna karşı politikası (1945-1970) / Ö. Kürkçüoğlu. — Ankara : Sevinç Matbaası, 1972. — 207 s.

9. Olaylarla Türk Dış Politikası (1919-1965). 2-ci baskı. — Ankara : Sevinç Matbaası, 1969. - $524 \mathrm{~s}$.

10. Soysal I. 1955. Bağdat Paktı / İ. Soysal // Belleten. - C. LV. - Sa. 212, Nisan. Ankara : Turk Tarih Kurumu Basımevi, 1991. — 295 s.

11. Soysal I. Seventy years of Turkish-Arab relations and an analysis of Turkish- Iraqi relations (1920 - 1990) / I. Soysal // Studies on Turkish-Arab relations. Annual 6. — Istanbul : Foundation for the Study of Turkish-Arab Relations [TAW], 1991. — S. 57.

12. Türkiye Ansiklopedisi - M.E.B. Devlet kitapları, 8-ci cilt. Cumhuriyet dönemi. Istanbul : İletişim Yayınları, 1983.

13. Ümman H. Orta Doğu buhranı / H. Ümman // A.Ü.S.B.F.D. - C. 13. - 1958. Aralık. — № 4. - Ss. 107, 237.

\section{Material resources}

Ama bu sefer de Suriye. (1955). Akis, 40: S. 17. (In Turk.).

Avcioğlu, D. (1957). Orta Doğudaki Boşluk. Akis, 147: S. 16. (In Turk.).

Avcioğlu, D. (1957). Bağdat pakt meselesine dair. Akis, 141: S. 14. (In Turk.).

Avcıoğlu, D. (1957). Orta Doğudaki Soğuk harp. Akis, 144: S. 17. (In Turk.).

Avcıoğlu, H. (1957). Orta Doğudaki Yeni Hava. Akis, 176: S. 17. (In Turk.).

Balkan, A. (1956). Dış Politikamız Ne Zaman Bir Düzene Kavuşacaktır? Akis, 100: S. 19. (In Turk.).

Balkan, A. (1957). Muharrem Nuri Birgi ile niçin mutabık değiliz. Akis, 139: S. 15. (In Turk.).

Başarılı işler. (1955). Akis, 37: S. 7, 8. (In Turk.).

Baş1 dertte Suriye. (1956). Akis, 139: S. 7. (In Turk.).

Bir politikanın başarısı. (1955). Akis, 34: S. 9. (In Turk.).

Çevrilen dirsek. (1956). Akis, 106: S. 19. (In Turk.).

Diş politika alfabesi. (1958). Akis, 220: S. 11. (In Turk.).

D1ş politikamız. (1955). Akis, 68: S. 11. (In Turk.).

Ergin, F. (1956). Haricî siyaset. Akis, 135: S. 9. (In Turk.).

Geçen yıla bakarken. (1956). Akis, 87: 12-13. (In Turk.).

Iki blok. (1956). Akis, 89: S. 17. (In Turk.).

Muhalefetle iktidarın birleştirdiği nokta. (1955). Akis, 40: S. 4. (In Turk.).

Müstafi milletvekilleri. (1957). Akis, 154: S. 13. (In Turk.).

Orta Doğu. (1954). Akis, 8: S. 11. (In Turk.).

Orta Doğu. (1955). Akis, 35: S. 9. (In Turk.). 
Orta Doğu. (1957). Akis, 140: S. 8. (In Turk.).

Orta Doğu. (1957). Akis, 147: S. 10. (In Turk.).

Orta Doğu. (1958). Akis, 196: S. 16. (In Turk.).

Orta Doğu. (1958). Akis, 198: S. 6. (In Turk.).

Orta Doğu. (1958). Akis, 199: S. 22. (In Turk.).

Sallanan pact. (1958). Akis, 194: S. 15. (In Turk.).

Süveyş. Fırtınadan sonar. (1956). Akis, 132: S. 14. (In Turk.).

Tarihi Arap dostlarımız. (1957). Akis, 189: S. 6. (In Turk.).

Toker, M. (1957). Mutabık olmadığımız politika. Akis, 144: S. 9. (In Turk.).

Toker, M. (1957). Kıbrıs politicası. Akis, 189: 8-9. (In Turk.).

Toker, M. (1958). Bağdatsız Bağdat Paktı. Akis, 198: S. 6, 9. (In Turk.).

Türkiye ve Orta Doğu. (1956). Akis, 134: S. 17. (In Turk.).

Ürdün. (1956). Akis, 89: 17-18. (In Turk.).

Zhukov, E. M. (ed.). (1969). CENTO. In: Soviet Historical Encyclopedia, 12. Moscow: Publishing house "Soviet Encyclopedia". 976 columns. (In Russ.).

\section{References}

Ağayev, E. (2010). Atatürk'ün Vefatının Sovyet Basınında Yansıması. In: Cumhuriyet Tarihi Araştırmaları Dergisi. Hacettepe Üniversitesi Atatürk İlkeleri ve Inkılap Tarihi Enstitüsü. 131-157. (In Turk.).

Aydemir, Ş. S. (1968). Íkinci adam: İsmet İnönü. Üçüncü ve Son Cilt (1950-1964). İstanbul: Remzi Kitabevi. 578 s. ISBN 9789751400376. (In Turk.).

Dış Politika. CHP. Araştırma ve Yıyın Bürosu. Yayın № 25. (1961). Ankara. 74 s. (In Turk.).

Eroğul, C. (1970). Demokrat Parti (Tarihi ve ideolojisi). Ankara: Ankara Üniversitesi. 227 s. (In Turk.).

Gürün, K. (1983). Dış ilişkiler ve Türk politikası (1939-den günümüze kadar). In: Ankara Üniversitesi Siyasal Bilgiler Fakültesi yayınları № 531. Ankara: A.Ü.S.B.F. 457 s. (In Turk.).

İnönü, İ. (1956). Muhalefetde. 1950 - 1956. Konuşmaları, demeçleri, mesajları, sohbetleri ve yazılarıla. İstanbul: Siralar Matbaası. 428 s. (In Turk.).

Kurban, V. (2014). 1950 - 1960 Yıllarında Türkiye ile Sovyetler birliği Arasındaki ilişkiler. In: Çăgdaş Türkiye Tarihi Araştırmaları Dergisi (Journal of modern Turkish history studies). 253-282. (In Turk.).

Kürkçüoğlu, Ö. (1972). Türkiyenin Arap Orta Doğusuna karşı politikası (1945-1970). Ankara: Sevinç Matbaası. 207 s. (In Turk.).

Olaylarla Türk Dış Politikası (1919-1965). 2-ci baskı. (1969). Ankara: Sevinç Matbaası. 524 s. (In Turk.).

Soysal, İ. (1991). 1955. Bağdat Paktı. In: Belleten. C. LV. Sa. 212, Nisan. Ankara: Turk Tarih Kurumu Basımevi. 295 s. (In Turk.).

Soysal, I. (1991). Seventy years of Turkish-Arab relations and an analysis of Turkish- Iraqi relations (1920 - 1990). In: Studies on Turkish-Arab relations. Annual 6. Istanbul: Foundation for the Study of Turkish-Arab Relations [TAW]. S. 57.

Türkiye Ansiklopedisi - M.E.B. Devlet kitapları, 8-ci cilt. Cumhuriyet dönemi. (1983). Istanbul: İletişim Yayınları. (In Turk.).

Ümman, H. (1958). Orta Doğu buhran1. A.Ü.S.B.F.D, 4: 107, 237. (In Turk.). 